\title{
AKTUALISASI PROFIL GURU NAHDLATUL ULAMA INSPIRATIF DALAM MENGHADAPI TANTANGAN REVOLUSI INDUSTRI 4.0
}

\author{
Oleh: \\ Sholihudin Al Ayubi ${ }^{1} \&$ Wildah Nurul Islami² \\ Email: sholihudinalayubialayubi@gmail.com \& \\ wildahnurulislami@gmail.com
}

\begin{abstract}
Inspirational teacher is a teacher who becomes a "mirror" for other teachers and has positive values in themselves for students and the surrounding environment. Among the current problems of NU teachers is how to deal with the development of information and communication technology with an inspiring role. The formulation of the problem in this study is "What is the form of actualizing the profile of inspiring NU teachers in facing the industrial revolution 4.0?" This study aims to analyze the actualization of the profile of inspiring NU teachers in facing the challenges of the industrial revolution 4.0. This research is a qualitative research using a conceptual approach. Date of collection methods using documentation and data analysis methods using qualitative descriptive analysis. The steps for actualizing the inspirational NU teacher profile include: 1. Examining the role of teachers and the challenges of the industrial revolution 4.0, 2. The importance of reflecting on the figure of KH. Hasyim Asy'ari was an inspiring figure of NU's ulama and teacher in the past but the results of his thoughts are still relevant to be applied in millennial times. Among the actualization forms of inspiring NU teacher profiles include three criteria namely ASWAJA's character, actively innovating, and actively literating.
\end{abstract}

Keywords: actualization, teacher profile, inspirational, industrial revolution

\section{Pendahuluan}

Guru adalah pejuang dan pahlawan dalam keberhasilan mutu pendidikan suatu bangsa. Profesi guru dituntut dengan berbagai varian model pembelajaran yang terencana dan bertarget sesuai kompetensi yang ingin dicapai. Sebagai sosok yang berilmu pengetahuan, guru mengemban tanggungjawab besar untuk mewujudkan misinya mencerdaskan peserta

\footnotetext{
${ }^{1}$ Dosen Sekolah Tinggi Agama Islam (STAI) Al-Azhar Gresik

${ }^{2}$ Dosen Sekolah Tinggi Agama Islam (STAI) Ar-Rosyid Surabaya
} 
didik. Dengan cara mentransfer ilmu, guru berproses sebagai pendidik dan pembimbing di sekolah setelah orang tua dan keluarga di rumah. Guru zaman milenial harus menjadi teladan bagi peserta didik dan menjadi inspirasi bagi masyarakat luas karena prestasinya, tidak hanya pada bidang pendidikan tapi juga bidang agama, sosial, dan ICT (Information and Communications Technologies).

Dalam dunia pendidikan, telah dikenal semboyan bermakna yang diungkapkan Ki Hajar Dewantara berbunyi: "Ing ngarsa sung tuladha, ing madya mangun karsa, tut wuri handayani." Ing ngarsa sung tuladha memberikan makna bahwa guru harus berperan sebagai figur teladan dan memiliki integritas, baik dalam konteks pribadi maupun lingkungan sosialnya. Ing madya mangun karsa memberikan makna bahwa guru dituntut untuk mampu sebagai penggerak inspiratif. Tut wuri handayani memberikan makna bahwa guru harus berkepribadian yang kuat. ${ }^{3}$ Semboyan yang dicetuskan oleh Bapak Pendidikan ini memberikan energi positif bahwa profesi guru sangat mulia karena mengemban peran yang bisa mencerdaskan anak bangsa sekaligus menguatkan kepribadiannya sebagai manusia.

Nahdhatul Ulama' sebagai organisasi komunitas muslim telah menunjukkan eksistensinya dalam hal pemberdayaaan guru, baik dari segi pemikiran maupun praktis. PERGUNU (Persatuan Guru NU) adalah salah satu badan otonom NU yang menaungi para guru, dosen, dan ustadz, serta berperan membantu menyelesaikan berbagai tantangan yang dihadapi di era Revolusi Industri. Problem guru NU saat ini adalah bagaimana menghadapi perkembangan teknologi informasi dan komunikasi dengan peran inspiratif yang harus dimiliki. Guru inspiratif adalah guru yang menjadi "cermin" bagi guru yang lain dan memiliki nilai-nilai positif dalam dirinya untuk anak didik dan lingkungan sekitarnya.

Menggagas profil guru NU yang inspiratif tidak mudah karena peserta didik sudah cerdas ICT, materi pelajaran lebih kompleks, peningkatan standar proses pembelajaran dan tuntutan capaian

${ }^{3}$ Soekartawi. Meningkatkan Efektifitas Mengajar (Jakarta: PT. Dunia Pustaka, 1995), 33. 
kemampuan berpikir siswa yang lebih tinggi. Meskipun tantangan Revolusi Industri 4.0 begitu besar, guru NU harus tetap berkarakter ahlu alsunnah wa al-jama'ah. Salah satu tokoh guru dan ulama besar yang inspiratif adalah KH. Hasyim Asy'ari melalui karya beliau yang berjudul "Adab al'Alim wa al-Muta'allim" sebagai kitab rujukan pedoman mendidik dengan karakter ahlus sunnah wal jamaah (Aswaja). Beliau adalah sosok yang dapat dijadikan cermin positif dalam keteladanan seorang guru milenial, meskipun hidup di zaman berbeda.

Atas dasar fenomena tantangan Revolusi Industri 4.0 yang berimplikasi pada pentingnya menggagas profil guru NU inspiratif, maka rumusan masalah dalam penelitian ini adalah "Bagaimana bentuk aktualisasi profil guru NU inspiratif dalam menghadapi Revolusi Industri 4.0?." Penelitian ini bertujuan menganalisis bentuk aktualisasi profil guru NU inspiratif dalam menghadapi tantangan Revolusi Industri 4.0. Penelitian ini diharapkan dapat memberikan manfaat bagi masyarakat, khususnya bagi para guru NU tentang profil guru NU inspiratif di era milenial yang sarat dengan berbagai problematika dan tantangan. Selain itu, juga diharapkan dapat memberikan kontribusi keilmuan bagi para akademisi bahwa guru NU juga harus bisa berkembang dan menyesuaikan diri dengan tantangan zaman tanpa menghilangkan jiwa Aswaja yang sudah ditanamkan dalam kehidupan sehari-hari.

\section{Metode dan Pendekatan Penelitian}

Metode penelitian ini termasuk jenis penelitian kualitatif dengan menggunakan pendekatan konseptual. Penelitian kualitatif adalah jenis penelitian yang secara umum dapat digunakan untuk penelitian kehidupan masyarakat, sejarah, tingkah laku, fungsionalisasi organisasi, aktivitas sosial, dan lain-lain. ${ }^{4}$ Dalam penelitian ini, data banyak berasal dari bahan pustaka yakni pengetahuan yang baru tentang fakta maupun gagasan mencakup buku, jurnal, dan bahan pustaka lainnya. Metode

${ }^{4}$ Pupu Saeful Rahmat, "Penelitian Kualitatif," Equilibrium, Vol. 5, No. 9 (JanuariJuni 2009), 2. 
pengumpulan data pada penelitian ini menggunakan dokumentasi dan metode analisis data dengan menggunakan analisis Miles dan Hubarman. ${ }^{5}$

\section{Hasil dan Pembahasan}

Aktualisasi profil guru NU dalam menghadapi tantangan Revolusi Industri 4.0 dapat dilakukan dengan sebuah proses yang bertahap, di antaranya:

\section{Menelaah Peran Guru NU dan Tantangan Revolusi Industri 4.0}

Era Revolusi Industri 4.0, guru menghadapi tantangan baru yakni bagaimana peran guru tidak dikalahkan dengan kemajuan teknologi digital. Melihat fenomena saat ini, peserta didik lebih cenderung menyukai belajar dan mencari sumber informasi materi pelajaran melalui aplikasi media gadget. Jika guru tidak kreatif dan inovatif, dia akan menjadi yang kedua setelah gadget. Strategi pembelajaran konvensional sudah tidak relevan lagi karena peserta didik pasti akan merasa jenuh dengan suasana di kelas.

Peran guru semakin penting karena mulai tahun 2019 pemerintah sedang mengupayakan untuk peningkatan mutu sumber daya manusia (SDM). Pembangunan mutu SDM berarti bertumpu pada guru, sehingga guru diharapkan menjadi agen transformasi penguatan SDM dalam membangun kemampuan peserta didik, menerapkan strategi pembelajaran yang inovatif, dan membentuk karakter positif generasi milenial. Salah satu upaya yang harus dilakukan adalah penguasaan guru dalam mengoperasikan dan mengeksplorasi ICT.

Guru NU harus siap menghadapi generasi milenial sebagai generasi yang lahir ketika internet sudah hadir dan menjadi sebuah tantangan. Generasi ini lahir pada tahun 1990-an, berumur antara 15-30 tahun. Mereka dikategorikan sebagai generasi digital native yang merupakan penduduk digital asli. Peserta didik berbeda dengan gurunya yang seorang digital migrant, yakni tidak lahir pada era digital tetapi harus mengadopsi dan

5 Muhamad Arif and Sulistianah Sulistianah, "Problems in 2013 Curriculum Implementation for Classroom Teachers in Madrasah Ibtidaiyah," Al-Ibtida Jurnal Pendidikan Guru MI Vol. 6, no. 1 (June 2019): 110-23, https://doi.org/10.24235/al.ibtida.snj.v6i1.3916. 
menyesuaikan diri dengan aspek-aspek teknologi. Kelompok ini adalah masyarakat yang berpindah dari era analog ke aera digital yang tidak serta merta menguasai kebiasaan-kebiasaan digital. Mereka memerlukan proses migrasi dan adaptasi. Satu-satunya jalan bagi guru adalah menyelami dan menguasai dunia digital peserta didiknya dengan belajar dan mengikuti pelatihan. ${ }^{6}$

Revolusi Industri 4.0 menimbulkan terjadinya perubahan di segala bidang akibat kemajuan teknologi dan komunikasi yang pesat. Dalam hal ini, ada konsekuensi dalam pembelajaran yang berdampak pada perilaku pembelajaran, alat atau media pembelajaran, dan proses pembelajaran. Dunia yang serba digital mengakibatkan perilaku kehidupan sangat bergantung pada perangkat digital. Interaksi yang dilakukan sarat dengan interaksi virtual dibandingkan dengan interaksi nyata. Oleh karena pembelajaran dilakukan secara virtual, proses ini dilakukan dengan metode pembelajaran jarak jauh di kelas virtual berbasis big data dengan cloud computing. Paradigma proses pembelajaran era milenial sarat dengan pembelajaran yang bersifat personalized, big capacity computerizing, dan distance learning. ${ }^{7}$

Guru NU adalah guru yang memiliki peran lebih besar karena selain dia harus menerapkan pembelajaran yang selaras dengan ajaran Aswaja, dia harus mampu menyesuaikan dengan zaman globalisasi dalam menerapkan metode pembelajaran di kelas. Karena perkembangan teknologi informasi dan komunikasi sudah tidak dapat dielakkan lagi, para guru NU harus cerdas ICT dan mampu menerapkan dalam pembelajaran. Fungsi PERGUNU harus lebih dimaksimalkan dengan membuka pelatihan ICT bagi guru yang belum melek teknologi agar mengubah mainstream konvensional menjadi modern. Menyadarkan pentingnya metode pembelajaran berbasis ICT bukan hal yang mudah karena bagi sebagian guru tidak mau disibukkan dengan persiapan yang matang dan rumit

${ }^{6}$ Rohmat Sulistya, "Heutagogi sebagai Pendekatan Pelatihan bagi Guru di Era Revolusi Industri 4.0," Jurnal Pendidikan dan Kebudayaan, Vol. 4, No 2, (Desember 2019), 130-131.

${ }^{7}$ Ibid., 132. 
dengan media ICT, apalagi tuntutan laporan kegiatan pembelajaran yang harus diselesaikan.

Saat ini, guru NU juga harus mempersiapkan diri menghadapi transformasi pembelajaran pedagogi menuju heutagogi. Pada pembelajaran pedagogi, peserta didik belajar dengan sadar karena membutuhkan sesuai kepentingannya dan guru sebagai pusat pembelajaran. Pada konsep heutologi, peran guru di sekolah sebagai pengontrol dan pengarah diminimalisasi karena peserta didik memiliki otonomi penuh untuk mengkontrol dirinya sendiri menjadi pembelajar yang aktif dan proaktif terhadap proses pembelajaran. Pendekatan ini menantang cara berpikir tentang belajar dan belajar, mendorong guru berpikir lebih pada proses daripada isi. ${ }^{8}$

Perancangan proses pembelajaran heotologi mencakup 3 tahap: (1) siswa dan guru bekerja sama untuk mengidentifikasi kebutuhan dan outcome pembelajaran, kemudian menyetujuinya dalam sebuah kontrak kesepakatan; (2) saat aktifitas pembelajarn berjalan, guru membuat task yang menantang untuk diselesaikan baik secara otonom maupun dengan bantuan; (3) pembelajaran dinilai berdasar outcome yang telah disepakati untuk melihat apakah outcome tersebut telah tercapai. ${ }^{9}$

\section{Pentingnya Bercermin pada Sosok Pemikir Inspiratif KH. Hasyim Asy'ari di Zaman Milenial}

Masyarakat mengenal KH. Hasyim Asy'ari sebagai tokoh ulama pendiri NU yang kharismatik dan banyak menulis kitab yang inspiratif, salah satunya adalah kitab Adab al-'Alim wa al-Muta'allim.10 Kitab ini membahas tentang masalah pendidikan terutama pendidikan etika. Pendidikan merupakan upaya pewarisan nilai-nilai luhur (transfer of moral)

${ }^{8}$ Ibid., 133.

${ }^{9}$ Ibid.

${ }^{10}$ Kitab ini secara keseluruhan terdiri dari delapan bab, sebagai berikut: 1 . Keutamaan ilmu dan ilmuwan serta pembelajaran 2. Adab bagi peserta didik 3. Adab peserta didik terhadap pendidik 4. Adab belajar bagi peserta didik 5. Adab bagi pendidik 6 . Adab mengajar bagi pendidik 7. Adab pendidik terhadap peserta didik 8. Adab menggunakan literatur dan alat-alat yang digunakan dalam belajar. Lihat Suwendi. Sejarah dan Pemikiran Pendidikan Islam (Jakarta: PT Raja Grafindo Pustaka, 2004), 143. 
dalam rangka berikhtiar 'memanusiakan manusia', disamping sebagai proses pengajaran ilmu pengetahuan (transfer of knowledge). ${ }^{11} \mathrm{Hal}$ ini sesuai dengan hakikat dan tujuan pendidikan itu sendiri, yakni sebagai upaya pembentukan dan pengembangan kepribadian manusia secara utuh sesuai dengan potensi atau fitrah yang dimiliki manusia. ${ }^{2}$ Prinsip pendidikan etika KH. Hasyim Asy'ari memang relevan dengan teori pendidikan bahwa guru harus mengarahkan peserta didik berkarakter yang sesuai dengan nilai ajaran agama dan sosial.

Hasil pemikiran beliau tentang pendidikan etika masih sangat urgen untuk diterapkan di zaman milenial ini. Dengan berkembangnya dunia digital, manusia cenderung tidak memperhatikan nilai-nilai etika, sehingga sebagai warga Nahdliyin masih membutuhkan rujukan kitab karya $\mathrm{KH}$. Hasyim Asy'ari. Misalnya, terkait kompetensi pedagogik dan keilmuan, KH. Hasyim Asy'ari di dalam kitabnya mengemukakan keharusan bagi guru agar selalu berusaha meningkatkan intelektualitasnya serta mengembangkan wawasan dan aktualisasi dirinya melalui kegiatan menulis (literasi). ${ }^{13}$ Kemudian terkait kompetensi kepribadian guru, KH. Hasyim Asy'ari menjelaskan bahwa seorang guru dituntut untuk senantiasa mendekatkan diri kepada Allah (murâqabah), bersikap tenang (sakînah) dan berhati-hati (wara') di dalam setiap langkah dan tindakan yang dilakukan. ${ }^{14}$

Dalam referensi lain disebutkan bahwa relasi antara guru dan peserta didik diharapkan dapat membangun komunikasi yang bersifat dinamis, konstruktif, dan dialogis. Dalam hal ini, KH. Hasyim Asy'ari menegaskan bahwa saat proses belajar mengajar berlangsung maupun di luar proses belajar, penghargaan dan penghormatan terhadap guru itu penting agar

(Yogyakarta:

${ }^{11}$ Imam Barnadib dan Sutari. Ilmu Pendidikan: Beberapa Aspek Substansial Penerbit Andi, 1996), 13.

${ }^{12}$ Jejen Musfah. Filsafat Pendidikan Akhlak Ibnu Miskawaih (Yogyakarta: Belukar Press, 2004), 18.

${ }^{13}$ Hasyim Asy'ari. Adab al-'Alim wa al-Muta'allim (Pondok Pesantren Tebuireng Jombang:

Maktabah At-Turats Al-Islamy, 1415 H), 55.

${ }^{14}$ Ibid., 68. 
tercipta suasana psikologis yang positif. Sebab, tanpa kehadiran guru, ilmu tidak akan ditransmisikan kepada peserta didik. Pola komunikasi dua arah harus dihidupkan dalam proses belajar mengajar karena guru adalah simbol dari moralitas, tidak hanya mengajarkan ilmu. ${ }^{15}$

Dalam lingkungan pesantren sangat ditekankan sebuah prinsip, lisan al-hal khoirun min lisan al-maqol yaitu keteladan jauh lebih diutamakan daripada orasi lisan. Di Magelang, ada sebuah lembaga pendidikan dengan metode seperti ini. Tingkat keberhasilannya pun sangat luar biasa karena mampu menciptakan kemandirian dan ketegasan dalam berpikir. Selain memberikan keteladanan, yang paling menarik, KH. Hasyim Asy'ari juga menegaskan pentingnya seorang guru mengembangkan tradisi menulis. Islam merupakan salah satu agama yang mampu melahirkan banyak karya di berbagai bidang keilmuan sepanjang sejarah peradaban Islam. Para guru seharusnya dapat melanjutkan tradisi tersebut dengan melakukan penelitian dan pengembangan untuk kelestarian khazanah Islam. ${ }^{16}$

\section{Aktualisasi Profil Guru NU Inspiratif dalam Menghadapi Tantangan Revolusi Industri 4.0}

Menggagas profil guru NU ispiratif tidak mudah dalam menghadapi tantangan Revolusi Industri 4.0. Langkah pertama yang bisa dilakukan adalah mengubah mainstream bahwa kita hidup tidak lagi di zaman konvensional, akan tetapi hidup di abad 21, yakni abad komunikasi tanpa batas yang menuntut guru berpikir cerdas dan kreatif dalam proses pembelajaran. Langkah kedua adalah guru tidak boleh menutup diri untuk menerapkan pembelajaran dengan media ICT. Para guru yang masih belum memahami perkembangan dunia digital harus aktif mengikuti pelatihan-pelatihan agar tidak ketinggalan zaman. Langkah ketiga adalah menjadikan pemikiran pendidikan etika KH. Hasyim Asy'ari sebagai pedoman dalam pembentukan karakter Aswaja.

${ }^{15}$ Zuhairi Misrawi. Hasyim Asyari; Moderasi, keumatan dan kebangsaan (Jakarta: PT. Kompas Media Nusantara, 2010), 230.

${ }^{16}$ Ibid., 232-233.

Volume 11 Nomor 1 Maret 2020 
Di era Revolusi Industri 4.0 ini, penting untuk aktualisasi profil guru NU yang membawa inspirasi bagi banyak orang. Ada tiga kriteria yang bisa diaktualisasikan, diantaranya:

\section{a. Guru NU harus tetap berkarakter ASWAJA}

Karakter Aswaja yang dimaksud adalah nilai-nilai yang diajarkan dalam paham ahl al-sunnah wa al-jama'ah terpatri dalam ucapan, sikap, dan pribadi seorang guru. Khittah NU menjelaskan 4 prinsip nilai Aswaja yang terdiri dari:

1) Sikap Tasamuh

Tasamuh bermakna toleransi yakni sikap tenggang rasa, saling menghormati dan saling menghargai sesama manusia untuk melaksanakan hak-haknya. Hal ini bisa dicontohkan pada guru NU yang mengajar di sekolah negeri yang peserta didiknya ada yang beragama selain Islam. Guru NU harus bersikap toleran terhadap anak didik yang berbeda agama tanpa membeda-bedakan, baik dalam hal perlakuan, penyampaian materi dan penilaian hasil belajar. Jika guru memperlakukan siswa lain yang berbeda agama dengan adil dan toleran (tidak fanatik), maka siswa tentu juga akan meneladaninya.

2) Sikap Tawasuth

Tawasuth adalah suatu langkah pengambilan jalan tengah bagi dua kutub pemikiran yang ekstrem (tatharruf) disertai dengan sikap aliqtishad (moderat). ${ }^{17}$ Tugas guru adalah menyebarkan paham moderat agar peserta didik tidak terjerumus dalam paham ekstrimisme yang sangat membahayakan dunia pendidikan. Hal ini bisa dicontohkan ketika ada beberapa siswa yang berbeda ajaran keagamaan dalam keluarganya misalnya antara NU dan bukan NU, mereka saling berdebat tentang pengamalan ajaran agama yang berbeda, maka guru bisa menengahi bahwa setiap orang berhak memiliki keyakinan dalam pengamalan ajaran agama. Guru harus memberi pemahaman untuk bersikap tawassuth (moderat) yakni tidak saling menyalahkan satu sama

${ }^{17}$ Achmad Muhibbin Zuhri. Pemikiran KH. M. Hasyim Asy'ari tentang Ahl alSunnah Wa al-Jama'ah (Surabaya: Khalista\&LTNPBNU, 2010), 61. 
lain, karena pada dasarnya semua sama benarnya, hanya berbeda madzhab yang diyakini.

Secara umum, manifestasi prinsip dan karakter al-tawasuth ini tampak pada segala bidang ajaran agama Islam dan harus dipertahankan, dipelihara, dan dikembangkan sebaik-baiknya, terutama oleh pengikut setia Aswaja. Manifestasi dari prinsip tersebut tercermin pada:

a) Bidang akidah, diantaranya tidak tergesa menjatuhkan vonis musyrik, kufur dan sebagainya atas mereka yang karena satu dan lain hal belum dapat memurnikan tauhid atau akidah secara murni. ${ }^{18}$

b) Bidang syari'ah, diantaranya pada masalah dhanniyyah (tidak tegas atau tidak pasti) dapat ditoleransi adanya pendapat, selama masih tidak bertentangan dengan prinsip agama.

c) Bidang mu'asharah (pergaulan) antar golongan, diantaranya mengakui watak dan tabiat manusia yang selalu senang berkelompok berdasar atas unsur pengikatnya masing-masing.

d) Bidang kehidupan bernegara, diantaranya negara nasional yang didirikan bersama oleh seluruh rakyat wajib dipertahankan dan dipelihara eksistensinya.

e) Bidang kebudayaan, diantaranya kebudayaan yang baik, dalam arti menurut norma agama, dari manapun datangnya dapat diterima dan dikembangkan dengan prinsip hal lama yang baik dipelihara dan dikembangkan, sedangkan yang baru dan lebih baik untuk dicari dan dimanfaatkan.

f) Bidang dakwah, diantaranya mengajak masyarakat untuk membuat dan menciptakan keadaan yang lebih baik, terutama menurut ajaran agama. ${ }^{19}$

18 Muhamad Arif, "Revitalisasi Pendidikan Aswaja an Nahdliyah (Ke-Nu-an) Dalam Menangkal Faham Radikalisme Di Smk Al-Azhar Menganti Gresik," J-PAI: Jurnal Pendidikan Agama Islam Vol. 5, no. 1 (July 2018): 15-25, https://doi.org/10.18860/jpai.v5i1.6052.

${ }^{19}$ Abdul Muchith Muzadi. NU dalam Perspektif Sejarah dan Ajaran (Refleksi 65 th. Ikut NU) (Surabaya; Kalista Surabaya, 2006), 71-73. 


\section{Sikap Tawazun}

Tawazun adalah sikap seimbang dalam berkhidmah. Menyerasikan khidmah kepada Allah Swt, khidmah kepada sesama manusia serta khidmah kepada lingkungan hidupnya. ${ }^{20}$ Guru harus tawazun dalam manajemen waktu dengan cara disiplin waktu antara kehidupan pribadi dan sosialnya. Guru harus komitmen dalam dirinya bahwa dia harus menyeimbangkan antara urusan pribadi dan sosial. Selain memenuhi kebutuhan untuk diri dan keluarganya, maka dia juga harus peduli lingkungan sekitarnya seperti mengikuti kerja bakti yang diadakan rutinan kampung, mengikuti kegiatan keagamaan kampung, memenuhi undangan tetangga yang memiliki hajat, dan lain-lain. Selain itu, dia juga harus peduli dengan kebersihan dan kesehatan lingkungan hidup.

\section{Amar Ma'ruf Nahi Munkar}

Amar Ma'ruf Nahi Munkar adalah melakukan hal yang diperintahkan oleh Allah dan menjauhi larangan-Nya. Artinya, seseorang harus selalu memiliki kepekaan untuk mendorong perbuatan baik, berguna dan bermanfaat bagi kehidupan bersama. Selain itu, seseorang harus menolak dan mencegah semua hal yang dapat menjerumuskan dan merendahkan nilai-nilai kehidupan. ${ }^{21}$ Guru harus senantiasa mengarahkan peserta didik ke arah yang baik dan mengingatkan mereka ketika berada di jalan yang salah. Misalnya, apabila mereka berada dalam perselisihan antar teman yang diwujudkan dalam tindakan kekerasan, guru harus bisa menjadi penengah dan pelerai untuk merubah sikap dan cara mereka menyelesaikan sebuah permasalahan. Peran guru sangat penting sebagai mediator dalam menumbuhkan kesadaran akan pentingnya persaudaraan dan bermusyawarah, tidak saling menyakiti antar teman.

Sebagaimana pemikiran KH. Hasyim Asy'ari bahwa seorang guru harus mencintai peserta didiknya melebihi cintanya pada dirinya. Ketika hal

${ }^{20}$ Harits, Busyairi. Islam NU Pengawal Tradisi Sunni Indonesia (Surabaya: Khalista, 2010), 120.

${ }^{21}$ Abdul Muchith Muzadi. NU dalam Perspektif Sejarah dan Ajaran, 27. 
ini diterapkan, maka akan ada kesatuan batin antara guru dan peserta didik seperti kasih sayang orang tua dan anak. Sebab itu, dibutuhkan kesabaran, ketelatenan, dan ketulusan. Dalam keseharian di kelas, para guru sering memanggil peserta didik dengan sebutan "anak-anak". Ungkapan ini menunjukkan bahwa telah terbangun sebuah komunikasi yang dapat membangkitkan psikologi pembelajaran.22 Jika terbangun pondasi komunikasi yang baik, maka untuk menjalankan amar ma'ruf nahi munkar semakin mudah sebagai upaya mencegah anarkisme dan problematika peserta didik lainnya.

\section{b. Guru NU harus aktif berinovasi}

Aktif berinovasi berarti guru harus aktif memperkenalkan metode pembelajaran yang baru atau mengkombinasikan sesuatu yang sudah ada menjadi lebih menarik. Salah satu bentuk aktualisasi metode inovatif adalah penerapan aplikasi e-learning sesuai materi pelajaran yang diampu. Keahlian ini bisa dilatih dengan mengikuti berbagai diklat pembelajaran berbasis ICT yang diadakan beberapa lembaga pendidikan. Guru harus mampu berinovasi membuat aplikasi sendiri yang dengan mudah diakses dan dipelajari secara mandiri oleh siswa mencakup materi pelajaran, soalsoal dan penerapan dalam kehidupan sehari-hari. Kemudian guru melakukan validasi dan penilaian pada tugas melalui media aplikasi tersebut.

Selain itu, guru juga bisa memanfaatkan media pembelajaran slide power point dan media proyektor untuk menjelaskan materi, bisa pula menampilkan video pembelajaran langsung melalui channel youtube yang dibuat sendiri oleh guru. Guru juga harus mulai memahami dan menerapkan metode HOTS (Higher Order Thinking Skills) yakni kemampuan berpikir tingkat tinggi dimana peserta didik bisa mengingat, memahami, mengaplikasikan, menganalisis, mengevaluasi dan menciptakan sesuatu. Peserta didik tidak hanya diajak memahami pelajaran hanya melalui media ICT, tapi juga diajak berpikir dan

${ }^{22}$ Zuhairi Misrawi. Hasyim Asy'ari..., 235.

Volume 11 Nomor 1 Maret 2020 
menganalisis materi, bisa langsung diajak ke alam atau tempat tertentu yang terkait materi.

Guru yang inovatif berarti mampu menerapkan model-model pembelajaran inovatif. Pembelajaran inovatif adalah pembelajaran yang sifatnya baru, berbeda dengan yang biasanya, bertujuan untuk mengkondisikan peserta didik agar dapat membangun pengetahuannya sendiri dalam rangka mencapai tujuan belajar yang lebih baik sesuai potensi yang dimiliki. Pembelajaran ini berbasis TIK yang menjadikan guru berperan sebagai fasilitator, dan menuntut pengembangan model pembelajaran student centered. Penerapan model pembelajaran seperti ini harus tetap diobservasi dan didokumentasikan untuk menjadi bahan sosialisasi pada sekolah-sekolah yang bisa dipraktikkan oleh guru di kelas. Hal ini bisa dicontohkan dengan penerapan portal rumah belajar yang memudahkan guru untuk membuat pembelajaran lebih menarik dan evaluasi belajar melalui fitur bank soal yang bisa diakses secara online. ${ }^{23}$

\section{c. Guru NU harus aktif berkarya (berliterasi)}

Aktif berkarya adalah ikut serta menggalakkan budaya literasi yang mencakup kegiatan membaca, menulis, dan menghasilkan karya dari hasil literasi. Diantara bentuk aktualisasinya adalah guru harus memiliki kompetensi di bidang akademik dan berkomitmen harus berkarya secara intensif melalui penyusunan karya tulis, baik itu berupa PTK (Penelitian Tindakan Kelas) atau menulis artikel ilmiah yang dipublikasikan. Karya yang dihasilkan oleh guru ini minimal dipublikasikan melalui sebuah blog pribadi. Blog pada zaman milenial ini dimaknai sebagai catatan pribadi atau artikel-artikel serta materi pelajaran maupun mata kuliah berupa bahan ajar yang dapat menunjang proses pembelajaran.

Selain berpengalaman menggunakan blog, guru juga harus aktif mengirimkan tulisan ke media massa. Guru harus cerdas menganalisis masalah global di masyarakat dan dunia pendidikan utamanya dalam menentukan tema yang ingin dikembangkan. Untuk pertama kalinya,

\footnotetext{
${ }^{23}$ Eni Susilawati, "Penerapan Model Pembelajaran Inovatif di SMP Pesat Bogor," Jurnal Teknodik, Vol. 23, No. 1, (Juni 2019), 42-44.
} 
memang guru harus siap ditolak oleh media massa karena tulisan kurang berbobot atau tidak up to date, namun hal itu bisa mendorong untuk memperbaiki diri dan tetap bersemangat mencoba terus hingga sukses menembus media massa. Guru juga harus aktif dalam perkumpulan para penulis, bisa via grup online maupun offline. Hal ini dilakukan agar bisa saling bertukar pikiran terkait pengembangan literasi, sebagai sumber inspirasi ketika memiliki relasi yang sudah sukses menulis, dan sebagai sumber informasi jika ada hal-hal penting seperti lomba menulis antar guru, bantuan penelitian untuk guru, dan lain-lain.

Untuk menunjang keaktifan berliterasi, guru harus intensif mengikuti kegiatan seminar yang membuka wawasan akan pentingnya pemanfaatan internet, khususnya kontribusi blog dalam peningkatan kompetensi menulis bagi guru. Kegiatan literasi ini harus dimulai dari guru sebagai contoh bagi peserta didik. Guru harus memberikan motivasi agar peserta didik suka menulis dan membiasakan mengerjakan tugas dalam bentuk karya tulis, misalnya: tugas membuat makalah, artikel, kliping, dan lain-lain. Guru bisa memanfaatkan media internet untuk mengirim data melalui email setiap tugas peserta didik. Untuk memperkaya pengalaman belajar dan peningkatan kualitas pembelajaran, dapat dilakukan pembelajaran online untuk kegiatan literasi peserta didik dengan berbagai program aplikasi yang ada, misalnya membantu mereka menggunakan $b \log$.

\section{Simpulan}

Guru NU zaman milenial harus menjadi teladan bagi peserta didik dan menjadi inspirasi bagi masyarakat luas karena prestasinya, tidak hanya pada bidang pendidikan tapi juga bidang agama, sosial, dan ICT (Information and Communications Technologies). KH. Hasyim Asy'ari adalah figur ulama dan guru NU inspiratif di masa lalu tapi hasil pemikiran beliau tentang pendidikan etika masih relevan diterapkan di zaman milenial. Hal ini karena salah satu prioritas pendidikan saat ini adalah pendidikan karakter (etika) dan wajib bagi guru NU untuk merujuk karya beliau Adab al-'Alim wa al-Muta'allim. 
Menggagas profil guru NU yang inspiratif tidak mudah, namun bisa diaktualisasikan dengan tiga kriteria yakni berkarakter Aswaja, aktif berinovasi, dan aktif berliterasi. Dengan berkarakter Aswaja, seorang guru akan berintegritas dan berkepribadian baik sesuai nilai-nilai yang diajarkan di dalamya. Dengan aktif berinovasi, seorang guru akan lebih terasah kecerdasan ICT dan tidak merasa terbebani dengan tantangan zaman yang menuntut untuk kreatif menggunakan media pembelajaran. Dengan aktif berliterasi, seorang guru akan luas wawasan dan daya berpikirnya berkembang karena pembiasaan menulis dan mempublikasikan karya.

\section{DAFTAR PUSTAKA}

Arif, Muhamad. 2018. "Revitalisasi Pendidikan Aswaja an Nahdliyah (KeNu-an) Dalam Menangkal Faham Radikalisme Di Smk Al-Azhar Menganti Gresik." J-PAI: Jurnal Pendidikan Agama Islam Vol. 5, no. 1 (July 2018): 15-25. https://doi.org/10.18860/jpai.v5i1.6052.

Arif, Muhamad, and Sulistianah Sulistianah. 2019. "Problems in 2013 Curriculum Implementation for Classroom Teachers in Madrasah Ibtidaiyah." Al-Ibtida Jurnal Pendidikan Guru MI Vol. 6, no. 1 (June 2019): 110-23. https:// doi.org/10.24235/al.ibtida.snj. v6i1.3916.

Asy'ari, M. Hasyim. 1415. H. Adab al-'Alim wa al-Muta'allim. Jombang: Maktabah al-Turath al-Islamy.

Harits, Busyairi. 2010. Islam NU Pengawal Tradisi Sunni Indonesia. Surabaya: Khalista.

Imam Barnadib dan Sutari. 1996. Ilmu Pendidikan: Beberapa Aspek Substansial. Yogyakarta: Penerbit Andi.

Misrawi, Zuhairi. 2010. Hasyim Asyari; Moderasi, Keumatan Dan Kebangsaan. Jakarta: PT. Kompas Media Nusantara.

Musfah, Jejen. 2004. Filsafat Pendidikan Akhlak Ibnu Miskawaih. Yogyakarta: Belukar Press. 
Muzadi, Abdul Muchith. 2006. NU Dalam Prespektif Sejarah Dan Ajaran (Refleksi 65 th. Ikut NU). Surabaya: Kalista Surabaya.

Rahmat, Pupu Saeful. 2009. "Penelitian Kualitatif," Equilibrium, Vol. 5, No. 9 (Januari-Juni 2009).

Soekartawi. 2995. Meningkatkan Efektifitas Mengajar. Jakarta: PT. Dunia Pustaka.

Sulistya, Rohmat. 2019. "Heutagogi sebagai Pendekatan Pelatihan bagi Guru di Era Revolusi Industri 4.0," Jurnal Pendidikan dan Kebudayaan, Vol. 4, No 2, (Desember 2019).

Susilawati, Eni. 2019. "Penerapan Model Pembelajaran Inovatif di SMP Pesat Bogor," Jurnal Teknodik, Vol. 23, No. 1, (Juni 2019).

Suwendi. 2004. Sejarah dan Pemikiran Pendidikan Islam. Jakarta: PT Raja Grafindo Pustaka.

Zuhri, Achmad Muhibbin. 2010. Pemikiran KH. M. Hasyim Asy'ari Tentang Ahl al-Sunnah Wa al-Jama'ah. Surabaya: Khalista \& LTN PBNU. 